\title{
Research on University Teaching Management Development Model
}

\author{
Wei Zhou ${ }^{1, a}$ \\ ${ }^{1}$ Jilin Agricultural University, Changchun, 130117, China \\ aemail: 652041717@qq.com
}

Keywords: University Teaching Management; Development model; Sustainable development

\begin{abstract}
Teaching management plays a very important role in the management of University, is closely related to the future development of China University education. With the continuous expansion of the scale of university, university education teaching management put forward higher requirements, to innovative management ideas and development models for long-term development of the University to provide reliable protection. According to the present situation of teaching management in universities are analyzed, presented to the university teaching management new direction and mode of development, to constantly improve the quality of university teaching, education meet the needs of business development, in order to achieve the sustainable development of university teaching.
\end{abstract}

\section{Introduction}

In university education, teaching management is very important work, with strong continuity, comprehensiveness and systemic characteristics such as education and university level rising are closely linked [1-2]. New directions for teaching management and development models to explore university, in favor of scientific and reasonable plan and organize university teaching process, to make university education resources are fully utilized, so as to promote university students' general ability and all-round development.

The present situation of university teaching management

In general, the contents of university teaching management include two aspects: planning management and process management, which are closely related to the development of students' comprehensive quality ability and the future development. With the continuous development of China's education reform, higher education has changed from elite education to mass education mode, which makes the number of students and the structure of the students have changed a lot. But in practice, the administrative mechanism of teaching management and related management system has not been timely improvement and innovation, elite teaching mode still exists, and between the development of modern education and the demands of social development does not adapt, there is a big difference in the status of teaching management and the traditional teaching mode, resulting in the university teaching management work efficiency is very low, bring some influence to the long-term development of the University. At the same time, number of university enrollment is increasing, a serious lack of scale expanding and teaching management personnel, particularly the lack of front-line teaching management personnel, resulting in university teaching management exists a lot of problems. At the same time, number of university enrollment is increasing, a serious lack of scale expanding and teaching management personnel, particularly the lack of front-line teaching management personnel, resulting in university teaching management exists a lot of problems[3].

According to the demand of the rapid development of Chinese university education, university teaching management personnel must have higher education, to a clear understanding of the professional needs and development direction, and must grasp the future development trend of the college students, to meet the social development of high-tech composite talents demand, adapted to the change of the teaching of the University, thus to university teaching management system is not 
perfect and provide strong support[4]. However, in the process of the development of Chinese university education, the teaching management evaluation system is not perfect, the teaching management experience is not mature, it has a great impact on the development of teaching management. In the actual process of teaching management, part of the University in order to cope with the examination and evaluation of teaching just pay more attention organize documents on teaching management, while ignoring the continuity of teaching file management, and incorrect ideas of teaching management and teaching management consciousness is not strong, resulting in university teaching lack of guidance of the correct target, resulting in the university teaching management is in disorder, university teaching management work efficiency is low. At the same time, the staff of teaching management work in Colleges and universities lack of effective communication between the, teaching management staff dissatisfaction with the status quo, no innovation spirit, professional skills are not high, resulting in university teaching management mode and structure of lagging behind, to the development of university students' comprehensive quality and ability to bring certain influence, so as to impede the development of teaching management in Colleges and universities.

\section{The new direction of university teaching management}

Innovative teaching concept, pay attention to the classification of teaching management

Modernization construction, the university to do a good job in the management of the teaching, we must advance with the times, innovative ideas of teaching management, teaching management and teaching plan will be combined together, improve the teaching plan implementation staff and teachers on teaching management understanding, full attention to the importance of teaching management, so as to improve the university teaching quality Only teaching management personnel and teachers' united front, holding the common teaching goal, can guarantee the effectiveness of teaching management, so that the teaching management can be truly implemented. Due to the teachers' professional teaching activities sill in the professional department. Therefore, university teaching management work center of gravity should put in the Department, of university teachers to give appropriate attention, to play a leading role of university teachers, the grade teaching management and make college and university teachers become the main body of the teaching management, so as to enhance teachers in the teaching and management work of the appeal. In the process of practice, teachers put in an important position, enhance the consciousness of teachers, the teaching aims to implement each teaching link, can help students better learning, so as to enhance the students comprehensive ability, and lay a solid foundation for the university students a good future development

Strengthen the team building, the implementation of teaching management

Teaching management team in Colleges and universities continue to grow, is very important to improve the efficiency of university teaching management. Therefore, the university teaching management work in order to carry out must pay attention to team construction, improve the level of teaching management team, the concentrated training, ensure that the increasing the effectiveness of university teaching management work by teaching management personnel between communicating and learning. University Leadership layer to encourage teaching administrators and teachers to strengthen interaction, to carry out a variety of teaching and research work, to innovate the teaching management, the teaching management team in Colleges and universities quickly enrich and strengthen, so as to enhance the ability of the overall management of the university teaching management team, to provide strong support for the university teaching management continues to move forward.

Pay attention to practical contact, improve the teaching management system

To continuously improve the efficiency of university teaching management, enhance the teaching management team, we must pay attention to practice, to improve the teaching management team in Colleges and universities of management mechanism and management system, to make the university teaching management toward standardization, standardization of development. Therefore, in the process of practice, teaching managers need to have a down-to-earth style of work, in strict 
accordance with the implementation of the system of rewards and penalties, will continue to improve the teachers to participate in the enthusiasm and initiative of teaching management, teaching management level has been improved rapidly. With the continuous innovation of Chinese education reform, college teaching management also need to continuous innovation, pay attention to the diversity and flexibility of management, to meet the needs of every link of the teaching, improving the adaptability of teaching management, ensure the quality of teaching.

\section{Development model of university teaching management}

\section{Teachers construction and teaching quality}

With the continuous development of economy, the continuous development of the university teaching management work, must continue to innovate management idea, and adapt to the development of society, so as to improve the university teaching quality, and promote the sustainable development of the higher education in China. Therefore, the development of university teaching management, we must pay attention to the construction of teachers and teaching quality, to ensure the basic construction of teaching management, so as to provide a reliable guarantee for the training of qualified socialist successors. In the process of practice, the university should pay attention to existing teachers' ability and skills, improve the teaching management and teachers' professional training, improvement of teachers comprehensive quality, the establishment of system stability, in the structure of teachers and professional leaders training management system, in order to cultivate the high-quality, high skill, high efficiency of teachers, provide strong support for university teaching management mode innovation.Conclusion

Based on the analysis of the mechanical theory as the foundation, designed the soccer robot pick the ball institutions optimal design process, found aim function, select design variables and the corresponding optimization algorithm to optimize a complete set of institutions. At last through the test to get the final performance parameters of the institution. Experiments show that the system has higher accuracy and stability, the new optimize pick the ball have design basic requirements, and achieved good ideal control effect.

Part time teachers and practical teaching

In the university teaching management process, to improve the students' practical ability is very important. Therefore, the development of university teaching management must focus on part-time teachers and practice teaching combining, hire a rich practical experience of part-time teachers, improve teaching quality, so as to promote college students' comprehensive quality and ability of comprehensive development. According to the development of college education and teaching management in universities need to cultivate a stable part-time teachers, strictly control the proportion of part-time teachers, has become an integral part of university teaching continuously enhance the strength.

Combination of teaching effect and teaching management evaluation

In order to promote the continuous improvement of university students' comprehensive quality and ability, teaching management in universities must pay attention to combination of evaluation of the effectiveness of teaching and teaching management, constantly improve teaching management mechanism, the establishment of effective teaching management quality guarantee mechanism and monitoring and evaluation mechanism, thereby to increase the students the proportion of practice teaching, let the students in practice and training process, enhance extracurricular survival ability, improve teaching effect, promote the continuous improvement of university students' practical ability. At the same time, strengthen the monitoring of teaching practice, and constantly improve the teaching practice of university evaluation system, enhance student learning enthusiasm and initiative, are effectively detected the weak link of each teaching practice, improve the efficiency of university teaching management, ensure a comprehensive assessment of various teaching links, so as to promote the University constantly improve the level of teaching management. 
The combination of teaching management and teaching management

In order to ensure the smooth progress of the work of teaching management in college, the university must hire have responsibility heart, rich experience of teaching supervision, combining the teaching management and teaching management and supervision, comprehensive and effective supervision of the teaching, so as to improve the teaching quality of College English teaching. In the process of practice regularly to teachers lecture to track and summarize, to teacher's teaching give a fair assessment and guidance, to strengthen students' learning effectiveness evaluation of teachers give the quantitative evaluation, to promote the rapid increase of university teaching level. In college education, only pay attention to the teaching of all aspects of teaching management, improve the enthusiasm of students and teachers, in order to truly improve the quality of teaching, promote the overall level of College teaching.

\section{Conclusion}

In summary, the modernization construction, the university teaching management work is an important core of the whole teaching process, and the development of students' comprehensive ability and the development of university education has a close relationship. In practice, the change of teaching management, teaching management mode innovation, improve the quality of university teaching, promote the reform and innovation of university education, and ultimately to promote the modernization of university teaching management in China.

\section{References}

[1] Rong R, Yang X, Chen Y, et al. The New Development of Education Management Informatization: Move Towards Smart Management[J]. China Educational Technology, 2014.

[2] Liu X, University D P. Under the Background of Informatization System Construction of University Education Management Research[J]. Theory Horizon, 2015.

[3] Gao F C. On the Construction of Teaching Management Informatization in the Colleges and Universities[J]. Theory \& Practice of Education, 2011.

[4] Qizhong O U, Zhang L. Research on the Construction of Undergraduate Teaching Resources Informatization Platform in Local Normal Universities and Colleges[C]// Computer Science and Education (ICCSE), 2010 5th International Conference on. IEEE, 2010:712 - 715. [2] HIROKIK, MINORUA, YASUOK, ET al.RoboCup: a challenge problem for AI and robotics. HirokiK. RoboCup-97: Robot Soccer World Cup [C]. Berlin: Springer, 1998.38-43. 